\title{
БОЙОВЕ МИСТЕЦТВО ЯК ЗАСІБ ДУХОВНОГО І ФІЗИЧНОГО ВИХОВАННЯ МОЛОДІ
}

\author{
Л. С. Рибалко \\ д. пед. н., професор, професор кафедри загальної педагогіки і педагогіки вищої школи, \\ Харківський національний педагогічний університет імені Г. С. Сковороди

\section{Д. С. Іванов} \\ здобувач вищого освітнього рівня «бакалавр» факультету фізичного вихованняі спорту, \\ Харківський національний педагогічний університет імені Г. С. Сковороди
}

Концепція Нової української школи (2016) наголошує на тому, що кожна дитина цілком неповторна й індивідуальна, унікальна від природи й талановита. А отже місія Нової української школи полягає в тому, щоб організовувати допомогу школярам, розкривати й розвивати їхні здібності й таланти на основі партнерства між педагогами, батьками й учнями.

Не дивлячись на оптимістичне декларування основних ідей освітньої політики, реальний стан здоров’я дітей як майбутнього української нації $є$ помітно незадовільним. У щорічній доповіді про стан здоров’я населення, санітарно-епідемічну ситуацію та результати діяльності системи охорони здоров'я України (2016) увага акцентована на тому, що реформування освіти в Україні без урахування стану здоров'я школярів вплинуло на їхню захворюваність. Негативно вплинули такі чинники: інформаційне перевантаження, стресогенні ситуації, обмеження фізичної активності (школярі постійно сидять за комп'ютером, їх цікавлять лише розважальні ігри), пасивна позиція дітей та сім’ї щодо власного здоров’я. У школярів реєструється найвища поширеність хвороб і накопичується хронічна патологія через незадовільну пристосованість до фізичних навантажень при недостатній тренованості й низькому рівні функціонального резерву серця.

У межах дослідження нами розроблено й проведено майстер-клас «Оволодіваємо елементами самооборони: джиу-джитсу» для старшокласників, учителів і батьків з метою пропагування ідеї бойового мистецтва як засобу духовного і фізичного виховання молоді, а завданнями - ознайомити учасників освітнього процесу в закладах загальної середньої освіти з технікою самооборони джиу-джитсу та сприяти інтересу до спортивних видів діяльності [1-5].

Обладнання - медалі, грамоти учасників змагань джиу-джитсу, відеоматеріали, складена нами таблиця «Поширені в Україні види східних і західних бойових мистецтв».

Інструктор - Д. С. Іванов, студент 4-го курсу факультету фізичного виховання і спорту Харківського національного педагогічного університету імені Г. С. Сковороди, спеціалізація - єдиноборства.

- План.

- Вступ.

- Співбесіда з метою розкриття особливостей джиу-джитсу.

- Вправи для самооборони.

- Завдання для самостійних занять фізичним вихованням.

- Висновки.

- Сценарій проведення майстер-класу.

1. Вступ.

Перша школа, у якій викладали джиу-джитсу, називалася Есин-рю, що в перекладі з японської мови означає «школа верби». Символ верби імітує сенс стилю джиу-джитсу. Як відомо, в природі верба «демонструє своє вміння бути м'якою і прогинатися під напором, але не ламатися». Вважається, що є притча, яка пояснює, чому саме верба стала символом цього складного мистецтва бою: «На вершині скелі біля обриву росли два дерева — верба і дуб. Час від часу дули сильні вітри. Дуб був міцним, жорстко стояв на своєму місці і ніякий вітер не міг його зрушити. Верба, коли дули сильні вітри, просто прогиналася під їх силою. Коли пориви вітрів закінчувалися, то вона випрямлялася назад, у вихідне положення. Але одного разу подув найсильніший вітер за весь час, коли росли ці дерева. Дуб не витримав: зламався і впав. Тим часом верба, як і зазвичай, прогнулася, а коли вітер покинув гору - знову стояла на ній у всій красі». Ця притча допомагає відповісти на питання: «Що ж це за бойове мистецтво джиу-джитсу?». Отже, головний принцип джиу-джитсу - бути жорстоким, коли це треба, але й вміти прогинатися, щоб потім випрямитися.

Ознайомлення з правилами техніки безпеки.

Усі учні зобов'язані пройти медичний огляд.

Учні заходять до зали лише з тренером.

Будь-які навантаження слід розпочинати з розминки.

Під час виконання вправ учні зобов’ язані бути дисциплінованими, уважними, чітко виконувати вказівки тренера.

Учні зобов'язані підтримувати чистоту та порядок у спортзалі. 
2. Співбесіда з метою розкриття особливостей джиу-джитсу.

2.1. У чому полягають відмінності джиу-джитсу від інших видів єдиноборств?

Майстри бойового мистецтва постійно вдосконалювали свої навички, оскільки вважали, що тільки таким чином вони зможуть пізнати істинний шлях воїна джиу-джитсу. Багатогранність цього бойового стилю і стала основною причиною, з якої воно набуло великої популярності в європейців після освоєння закритої Японії. Свого часу від основної школи джиу-джитсу відокремились і виросли два окремих стилю - дзюдо й айкідо.

Кожен вид бойових мистецтв має власні правила. Для єдиноборств використовують майданчики, покриті татамі або іншими матеріалами, найменші габарити яких не менше 8x8 м. Цю територію поділяють на дві зони: робочу (6х6 м) і небезпечну (не менше 2 м) і позначають майданчик різними кольорами. Бій тривалістю 3 хвилини проходить у робочій зоні. Правилами дозволено наносити удари як руками, так і ногами по тілу, а також у голову конкурента. Використання больових і задушливих методів дозволено тільки в партері й стійці.

Удари не такі гарні, як в карате або тхеквондо, немає видовищних ударів ногами й стрибків із розвороту. Дозволено нанесення ударів у партері і ліктями. Способів захоплення больового впливу на зап'ястя руки $€ 32$ види. А ще заломи пальців, суглобів рук і ніг, дія на хребет і на акупунктурні точки, а також безліч задушливих прийомів. Кидкова техніка рясніє масою прийомів. Вона обрана як основа у таких видів боротьби як самбо, айкідо, рукопашний бій.

Раніше це мистецтво нечасто траплялося серед нижчих шарів населення, що не мали права носити зброю. Основним принципом служить використання сили супротивника проти нього самого. Борець не чинить опір силі, а спрямовує іiі в потрібне русло.

2.2. Що таке бразильське джиу-джитсу?

Бразильська техніка виникла завдяки відомому Мітсуйо Маеда, який мандрував, популяризуючи напрямок дзюдо. У Бразилії він почав навчати людей методикам і прийомам боротьби, а його вихованець організував власну школу, що розвивалася, у ній модифікувалася техніка єдиноборств, поліпшувалися прийоми, i в результаті з'явився новий стиль, що називають бразильське джиу-джитсу.

2.3. Що таке система поясів джиу-джитсу?

Джиу-джитсу має свою градацію й рейтинг поясів, що видаються послідовникам за їхню майстерність у володінні стилем. Білий пояс видається учневі, який тільки почав навчатися джиу-джитсу. Білий колір символізує чистий аркуш, на який шляхом тренувань будуть накладатися навички та вміння. Жовтий пояс означає, що учень вже завчив деякі прийоми джиу-джитсу й техніки самооборони. Підкреслимо використане слова «завчив», так як це поняття відрізняється від «опанував». Червоний пояс говорить про те, що учень опанував швидкісні й сильні удари, а також відчув небезпеку від зброї. Зелений пояс видається учневі, який впевнено став на шлях пізнання, розуміє тактику джиу-джитсу, його мету, а також володіє більшістю базових прийомів. Синій пояс означає, що учень опанував методи психологічного тиску джиу-джитсу й може їх застосовувати, усвідомлюючи їхню небезпеку. Коричневий пояс видається учневі, який вирішив повністю пов'язати своє життя з цим бойовим мистецтвом. Чорний пояс символізує рівень учня, який відкрив своє серце й поселив у ньому мистецтво джиу-джитсу. На ньому вишивають ім’я власника та його дан як ступінь високої майстерності.

Хотілося б сказати, що в джиу-джитсу пояса є розпізнавальним знаком майстерності учнів і характеризують їхні реальні вміння, оскільки без наполегливої праці їх отримати неможливо.

2.4. Яким чином можна досягати бажаних результатів?

Структура занять та програма підготовки рукопашного бою, що застосовується на постійних тренуваннях, дозволяє ефективно засвоїти навчальний матеріал протягом навчального року, досягнути позитивних функціональних змін в організмі кожного учня.

У процесі занять бойовими мистецтвами, завдяки історичним традиціям та етичним вимогам кожного стилю, важливими є стійкі звички до самодисципліни. Так наприклад, в школі «Самсон-Право», як і в деяких інших східних єдиноборствах, учневі не дозволяється заходити в зал після вчителя. Тому, щоб не запізнюватись на тренування, учень повинен навчитись раціонально використовувати свій час протягом доби. Та ще чіткі вимоги поясової атестації в рукопашному бою вимагають певних знань та навичок щодо особистої гігієни спортсмена.

2.5. Як сприяти виявленню інтересу до фізичного виховання в процесі занять джиу-джитсу?

Існують різні способи мотивації молоді до фізичного виховання, занять фізичними вправами: демонстрація позитивних впливів від фізичних навантажень; інтерес до нової справи; цікаві форми проведення секційних занять; можливість самоствердитися в оточенні та в змаганні з іншими; можливість мати красиве тіло; бути здоровим і зовнішньо привабливим; для розвитку кар'єрних можливостей; наслідування кумира; можливість проведення, спільно з друзями, цікавого і корисного дозвілля тощо.

Бойові мистецтва можуть зацікавити дітей трюками, що видовищно виглядають у виконанні майстрів. Ніхто не скасовував і самооборону, адже у сучасному житті це важливо і дуже потрібно для дитини — вміти 
постояти за себе й дати відсіч. У цілому, заняття бойовими мистецтвами позитивно впливають на поведінку дітей, їхню свідомість та життєвий шлях.

На перший погляд, заняття бойовими мистецтвами не виглядають чудовою ідеєю, оскільки, згідно з багатьма фільмами, телевізійними шоу, відео- й комп'ютерними іграми вони прославляють і заохочують насильство. Однак, ми переконані, що бойові мистецтва насправді далекі від цього, більше того, заняття єдиноборствами дозволяють дітям отримувати величезну користь для фізичного й особистісного розвитку.

2.6. Чим корисні бойові мистецтва, щоб переконати в цьому батьків і школярів? Чи може навчання бойового мистецтва спонукати до насильства?

Кожен інструктор може навести безліч прикладів із власної практики, коли його учні одночасно 3 підвищенням рівня майстерності позбавлялися поганих звичок, знаходили гідних друзів і навіть дивним чином самі змінювалися в позитивну сторону. Усі ці зміни безпосередньо пов'язані з підвищенням самооцінки школярів та із зростанням їх впевненості в собі.

Володіючи позитивної самооцінкою, учень не потребує таких штучних стимуляторів власного образу, як наркотики, алкоголь, вуличні компанії, кримінальна діяльність і безліч інших порочних видів активності, що прагнуть «заманити у свої пастки». Коли учень залишається задоволеним собою, у нього виникає почуття самоповаги. А це дозволяє йому розуміти значущість фізичного виховання, прагнути до цього та постійно вдосконалювати власний потенціал. Метою фізичного виховання є передусім створення умов для зміни поведінкових моделей учня. Якщо процес занять не викликає таких змін, то він не має виховної цінності. Ще більш важливо, щоб ці зміни були спрямовані в позитивне русло. Це мають бути, безперечно, конструктивні, чіткі та стійкі зміни, що сприятимуть досягненням учнем поставленої перед собою мети. Такі зміни мають бути корисними й для самого учня, і для оточуючого середовища, у якому він мешкає.

Заняття бойовими мистецтвами покращують концентрацію й самодисципліну людини, вони зазвичай починаються з поклону майстру та вправ на розминку. Потім діти виробляють різні навички, зокрема удари руками й ногами. Усі ці вправи вимагають концентрації й самодисципліни. Батьки відзначають, що їхні діти, особливо діти із синдромом дефіциту уваги й гіперактивності, успішно розвивають ці навички.

Школярі покращують власну фізичну й спортивну форму, роблячи розминку, що передбачає стрибки, розтяжку, віджимання й інші вправи, необхідні для оволодіння бойовими мистецтвами. Ці вправи зміцнюють м'язи й дозовано навантажують серцево-судинну систему. Ось чому тіла майстрів бойових мистецтв добре фізично розвинені, гнучкі й мають хороший тонус. Тіло вашої дитини може стати таким самим.

Учні вчаться захищати себе від можливих кривдників. Більшість спортивних експертів у своїх програмах навчання роблять акцент на самооборону. I хоча навички в різних єдиноборствах можуть відрізнятись, у результаті систематичних тренувань діти набувають чудового вміння захищати себе. Тренери з бойових мистецтв також навчають дітей правильно поводитися на вулиці, що дозволяє уникнути проблем 3 хуліганами.

Школярі починають учитися поваги з того моменту, як переступають поріг спортивної школи. Вони вчаться кланятись майстрам та інструкторам. Потім юні спортсмени вчаться ставитись до інших учнів так, як вони хочуть, щоб ті ставились до них. У бойових мистецтвах удари руками, ногами й інші рухи виконуються, однозначно, з почуттям поваги. Досвідчені інструктори бойових мистецтв завжди підкреслюють значення поваги та вчать своїх учнів бути ввічливими з учителями, батьками та однолітками.

Учні, які займаються бойовими мистецтвами, стають упевненими в собі. Система отримання різних поясів допомагає дівчатам та хлопцям ставити перед собою вимірні й реалістичні цілі. Оволодіваючи новою технікою або отримуючи більш високий пояс, школярі відчувають почуття досягнення результату, що супроводжує їх у подальшому житті.

На заняттях з бойового мистецтва виховується командний дух, маленькі спортсмени вчаться займатись не тільки самостійно, а й разом зі своїми тренерами та іншими учнями. Вони допомагають один одному опановувати нові прийоми, отримувати нові пояси й домагатись поставлених цілей на спарингах та інших спортивних заходах.

Бойові мистецтва допомагають людині вивчити прийоми самооборони, а не насильства, а також покращити навички спілкування. Більшість шкіл бойових мистецтв навчає школярів ненасильницьким навичкам вирішення конфліктів і підкреслюють важливість недопущення фізичного протистояння.

Зазначимо, що старшокласникам важливо пам'ятати: вибір професії також пов'язаний з фізичним розвитком. Так, заняття бойовими мистецтвами допомагають адаптуватися абітурієнтам до військових професій, що останнім часом є контрактними.

Коли дитині варто починати займатись єдиноборствами? Як правильно вибрати для малюка вид єдиноборства?

Діти можуть починати вивчення бойових мистецтв із шести років, тому що до цього віку вони вже набувають здатності контролювати власні удари руками, ногами й повороти тіла. Хоча деякі школи єдиноборств пропонують навчання для дітей молодшого віку. Їхні програми, як правило, орієнтовані на ігрову форму занять, 
тому при переході в старші групи, до більш структурованих програм, діти можуть виявитись непідготовленими в достатній мірі.

Фахівці рекомендують вибирати ті школи, що суворо дотримуються традиційних принципів конкретного бойового мистецтва. Відповідно, не рекомендується вибирати секцію, де джиу-джитсу переплітається з кікбоксингом. Ваша дитина отримає більше користі у школах, що навчають чистого єдиноборства.

Як ми вже зазначали, раніше це мистецтво нечасто поширювалося в нижчих шарах населення, що не мало права носити зброю. Сьогодні осягнути його набагато простіше, досить подивитися відеоурок.

2.8. Яким має бути харчування юного спортсмена?

Залежно від періоду підготовчих тренувань і завдань спортивних занять, харчування може відрізнятися. Так, у період накопичення - базове харчування в умовах звичайних тренувань; харчування перед змаганнями; період реалізації - під час змагань. Раціон спортсменів, котрі займаються єдиноборством, має містити багато білка, оскільки швидкісно-силові навантаження сприяють перебудові м'язів (це може бути 13-18\% загального калорійного раціону або близько 1,2 -1,6 г/кг ваги, а в період нарощування м'язів до 2 г/кг). Вуглеводів, безумовно, також має бути багато, оскільки вони є джерелом енергії при аеробно-анаеробних навантаженнях. Під час зниження ваги тіла потрібна вода, її потрібно досить багато.

\section{3. Вправи для самооборони.}

3.1.Удар коліном в пах. Цей прийом в класичному виконанні являє собою удар в пах або захоплення мошонки, так як ця зона - найбільш вразлива у чоловіків. Якщо сильно вдарити нападника в це місце, він рефлекторно відпустить руки, у результаті у вас з'явиться можливість звільнитися від захоплення. Зверніть увагу: бити потрібно максимально жорстко, так як слабкі спроби лише розлютять вашого супротивника.

3.2. Удар в горло. Простий прийом самооборони, що обов’язково включає такий важливий удар,

3.3. Удар по носу ребром долоні. Цей удар потрібно наносити ребром долоні по носу або в ділянці верхньої губи. Це відмінний спосіб захистити себе від нападу. Його потрібно наносити в горизонтальній площині розкритою долонею з відтяжкою. Найбільш ефективний варіант застосування — прихований удар, тобто ви начебто просите про пощаду, складаючи руки перед грудьми.

3.4. Удар по вухах .Цей відомий удар наноситься відкритими долонями, складеними трохи човником, одночасно за двома вухам супротивника. Головна вимога - він повинен бути різким і сильним. Необхідно використовувати інерцію й вагу свого тіла, і тоді цей прийом може призвести до розриву барабанної перетинки або сильного больового шоку.

3.5. Хльостаючі удари по обличчю. Цей прийом вважається типово жіночим. Для його застосування потрібно трохи розгорнути корпус і викинути руку вперед: плече, потім лікоть і кисть, що вистрілює знизу вгору хльостом. У якості ударної поверхні можна використовувати кісточки пальців, ребро долоні або ії̈ тильну сторону.

\section{4. Завдання для самостійних занять фізичним вихованням.}

Для самостійних занять достатньо в домашніх умовах виконувати елементарні вправи з фізичної культури. Це можуть бути звичайні згинання-розгинання рук в упорі лежачи (віджимання), скручування тулуба лежачи на спині, присідання. Цих простих вправ буде достатньо для підтримування форми та гарного самопочуття.

Висновки. Інструктор Д. Іванов «Я займаюся джиу-джитсу 7 років і з власного досвіду можу сказати, що це не просто вид спорту, а ще й філософія, що мені допомагає в повсякденному житті долати різні труднощі та виходити переможцем зі скрутних положень. Тому я пропоную вам займатись саме цим видом спорту». Таким чином, бойове мистецтво є цікавим і потрібним видом спорту для духовного і фізичного виховання молоді.

\section{Література}

1. Концепція Джиу-джитсу // Bсе о єдиноборствах. URL: http://martialsport.ru/dzhiu-dzhitsu.html.

2. Овчинников В. Ветка сакуры. Рассказ о том, что за люди японцы. Сакура и дуб : сборник. URL : http://qoo.by/41wJ.

3. Основной принцип джиу джитсу: «поддаться, чтобы победить». URL: https:/ok.ru/bushidoby/topic/65041671197960.

4. Особенности джиу джитсу. URL: http://jiu-jitsu.com.ua/articles/osobennosty-jiu-jitsu.php.

5. Что такое джиу джитсу: правила, приемы, пояса. URL: https://nasporte.guru/boevye-iskusstva/chto-takoe-dzhiu-dzhitsupravila-priemy-poyasa.html. 